\section{ПОРІВНЯЛЬНИЙ АНАЛІЗ ПОДАТКОВИХ СИСТЕМ УКРАЇНИ, РЕСПУБЛІКИ БІЛОРУСЬ ТА КРАЇН ПРИБАЛТИКИ}

\author{
БECCOHOBA A. B., \\ асистент кафедри обліку і аудиту \\ ДВНЗ «Приазовський державний \\ технічний університет»
}

COMPARATIVE ANALYSIS OF TAX SYSTEMS OF UKRAINE, THE REPUBLIC OF BELARUS AND THE BALTIC COUNTRIES

\author{
BESSONOVA A., \\ Assistant Professor of the \\ Dpartment of Accounting and \\ Auditing, SHEl «Priazovsky State \\ Technical University»
}

У статі проведено порівняльний аналіз систем оподаткування України, Республіки Білорусь та країн Прибалтики. Автором досліджено ставки основних податків аналізованих країн та вплив податкового навантаження на рівень життя у країні. Визначено вплив прогресивного оподаткування на розвиток економічної системи країни.

Ключові слова: податок; податкова система; ставка податку; збір; соціальне страхування.

В статье проведен сравнительный анализ систем налогообложения Украины, Республики Беларусь и стран Прибалтики. Автором исследованы ставки основных налогов рассматриваемых стран и влияние налоговой нагрузки на уровень жизни в стране. Определено влияние прогрессивного налогообложения на развитие экономической системы страны.

Ключевые слова: налог; налоговая система; ставка налога; сбор; социальное страхование.

The article provides a comparative analysis of the taxation systems of Ukraine, the Republic of Belarus and the Baltic countries. The author investigated the rates of the main taxes of the countries under consideration and the influence of the tax burden on the standard of living in the country. The influence of progressive taxation on the development of the country's economic system has been determined.

Keywords: tax; tax system; tax rate; levy; social security.

Постановка проблеми. Податкова система - основа функціонування будь-якої держави, адже бюджет країни формується і наповнюється переважно саме за рахунок податків та зборів. 31991 року податкова система України знаходиться у стані постійної реформації, відходячи від специфіки радянського оподаткування та намагаючись набути власну, унікальну податкову політику, що повною мірою відповідала 6 специфічним умовам конкретної країни та вимогам сучасності.

У свою чергу, Республіка Білорусь $€$ менш прогресивною країною, чия політика досить є залежною від Росії, отже, й податкова система довгий час залишалася майже незмінною та відносно стабільною. Але політичні події 2020 року з масовими протестами залишили свій слід в оподаткуванні Білорусі, переважно негативний. Суттєво збільшилися штрафи та податки на деякі види діяльності, були скасовані пільги у сфері IT.

Країни Прибалтики (Латвія, Литва, Естонія) також $є$ пострадянськими, але у наш час перебувають у зовсім іншій політичній системі, Євросоюзі, тому й оподаткування у цих країнах значно 
відрізняється від інших колишніх радянських республік і знаходиться у стані адаптації до європейських стандартів.

Саме через відмінні політичні умови автором були обрані саме Україна, як країна, що розірвала зв'язок з Росією та іншими пострадянськими країнами та поступово рухається до союзу 3 Європою, Білорусь, як країна, що залишається у тісному взаємозв'язку з Росією, та країни Прибалтики, що є частиною Євросоюзу та мають зовсім інші системи оподаткування.

Аналіз останніх досліджень і публікацій. Дослідження питань розвитку податкової системи будь-якої країни, що розвивається, привертає увагу не лише широкого кола науковців, а й міжнародної спільноти в цілому. Вплив розміру податкових ставок та загальної системи оподаткування досліджується багатьма міжнародними аналітичними центрами, які формують відповідні рейтинги країн на основі проведеного аналізу. Наприклад, рейтинг країн світу за рівнем щастя їхнього населення [8], рейтинг країн за рівнем життя [9]. В основу цих досліджень полягає багато факторів, і податкова система країни є невід'ємною в обох випадках.

Мета статті. Метою даної статті $€$ аналіз податкових систем України, Білорусі та країн Прибалтики, дослідження їхньої специфіки, спільних та відмінних рис.

Виклад основного матеріалу. Згідно офіційного словника Державної фіскальної служби України, податкова система країни - це сукупність податків, зборів, інших платежів та внесків до бюджету і державних цільових фондів, платників податків та органів, що здійснюють контроль за правильністю обчислення, повнотою і вчасністю сплати їх у встановленому законом порядку [1]. У Податковому кодексі України детально розкриті принципи оподаткування:

1) загальність оподаткування;

2) рівність платників перед законом;

3) презумпція правомірності;

4) фіскальна достатність;

5) соціальна справедливість;

6) економічність та нейтральність оподаткування;

7) стабільність;

8) рівномірність та зручність сплати;

9) єдиний підхід до встановлення податків і зборів [2].

Загалом податкова система України складається 3 загальнодержавних та місцевих податків та зборів (рис. 1). 


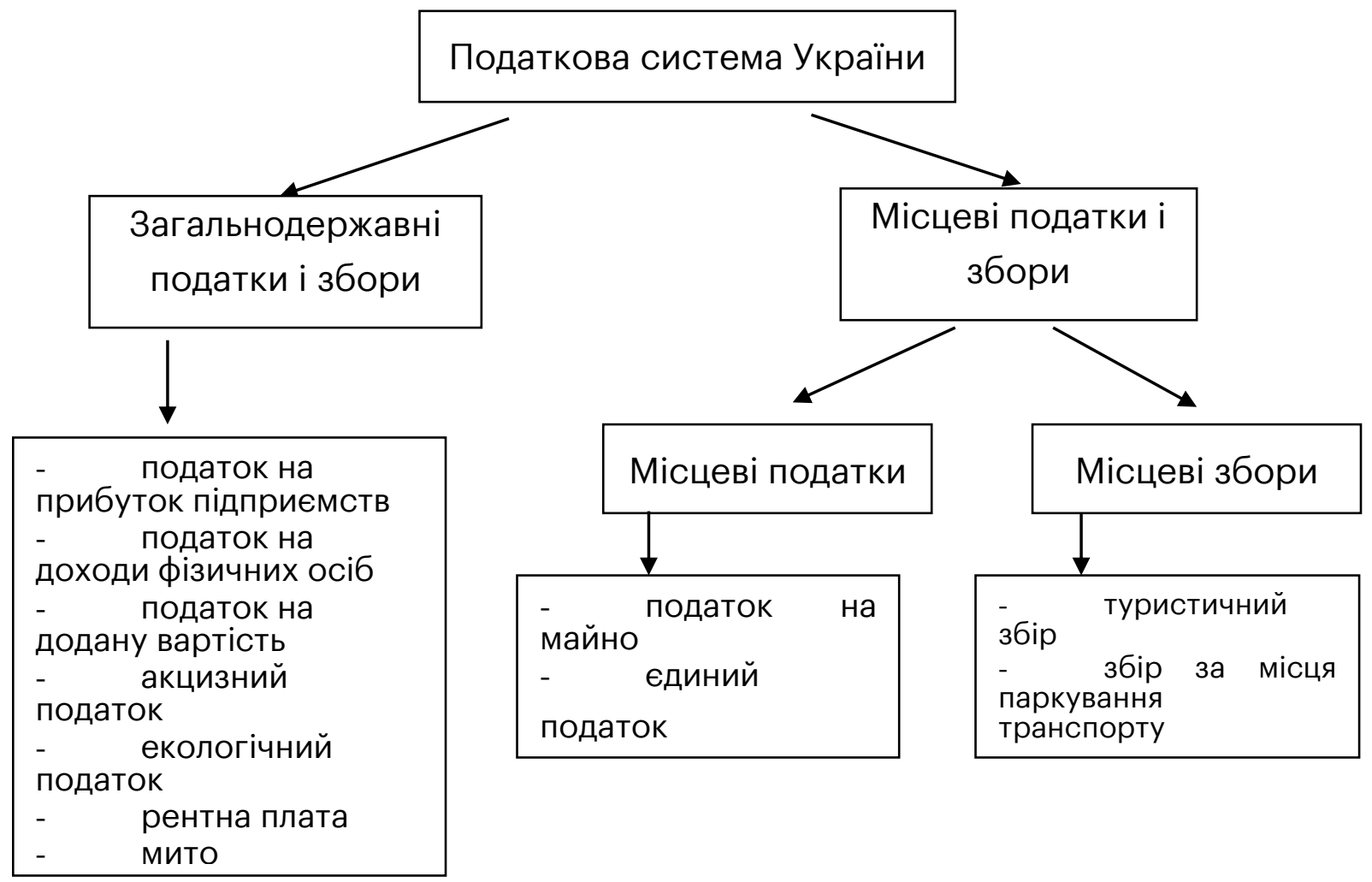

Рис. 1. Характеристика системи податків і зборів України (складено автором)

1) Податок на прибуток. Основна ставка - 18\%, ставки податку у випадку проведення страхової діяльності - 3\% та 0\% (за умови довгострокового страхування життя, медичного страхування та недержавного пенсійного забезпечення).

2) Податок на доходи фізичних осіб (ПДФО). Основною ставкою ПДФО є 18\%, у деяких випадках використовуються ставки 5\% і $0 \%$.

3) Єдиний соціальний внесок на загальнообов'язкове державне соціальне страхування (ЄСВ). Основна ставка - 22\%. Також у випадках працюючих інвалідів застосовуються ставки 8,41\%, 5,5\%, 5,3\% [3].

Податкова система Республіки Білорусь складається 328 податків і зборів. Однак при звичайній діяльності сплачується тільки 5 платежів: податок на додану вартість, податок на прибуток, податок на нерухомість, земельний податок, відрахування до Фонду соціального захисту населення. Як і в Україні, податкова система Білорусі також $€$ дворівневою: податки діляться на республіканські і місцеві [4]. Детальна характеристика приведена на рисунку 2: 


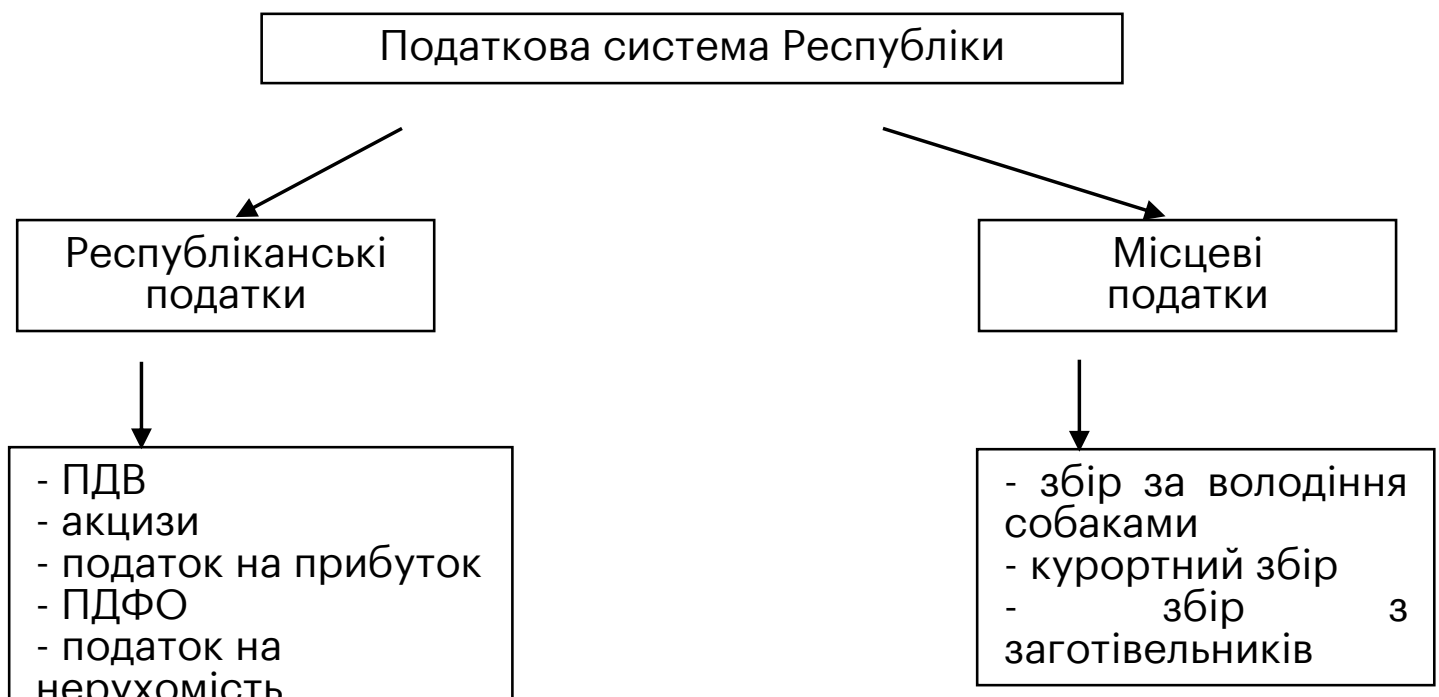

(складено автором)

Рис. 2. Характеристика системи податків і зборів Республіки

- екологічний податок

- податок на

добування природних

ресурсів

- земельний податок

- офшорний збір

- гербовий збір

- консульський збір

- державне мито Білорусі:

Ставки основних податків та зборів, що утримуються на території

1) Податок на додану вартість. Основною ставкою оподаткування $€ 20 \%$, однак існує ряд товарів і послуг, для яких передбачені ставки 10\% та 0\%.

2) Податок на прибуток. Основна ставка податку - 18\%. Але існують окремі ставки для конкретних видів діяльності: науковотехнологічні парки (10\%), банки (25\%), оператори мобільного зв'язку (30\%).

3) Податок на доходи фізичних осіб. Основною ставкою $є 13 \%$, але індивідуальні підприємці зобов'язані платити 16\% [5].

4) Єдиний внесок у Фонд соціального захисту населення (ФСЗН). Ставкою оподаткування $€ 34 \%$, також існує обов'язкове страхування від нещасних випадків на виробництві у розмірі 0,6\% [6].

Країни Прибалтики, у свою чергу, використовують прогресивні ставки податків, які залежать від суми доходу та кількості працівників на підприємстві (у випадку сплати податку на прибуток). Лише в Естонії ставки податків залишаються фіксованими, а найбільша диференціація оподаткування притаманна Литві. Отже, у Прибалтиці діють наступні податкові ставки:

1) Податок на додану вартість. Естонія: основна ставка 20\%, також використовується ставка 9\% (на медикаменти, періодичні видання та підручники); Латвія: основна ставка 21\%, також існують ставки у $12 \%$ (медикаменти, навчальна та періодична література, дитяче харчування, внутрішні пасажирські перевезення); Литва: 
основна ставка 21\%, застосовуються ставки 9\% (книги та неперіодичні видання, постачання опалення та гарячої води, регулярні пасажирські перевезення), 5\% (медикаменти, періодичні видання, обладнання для інвалідів) та О\% на прилади тестування та вакцини від COVID-19.

2) Податок на прибуток. Естонія: основна ставка 20\%, також використовується ставка $14 \%$ у випадку регулярного розподілу прибутку. Латвія: основна ставка 20\%, але якщо організація $€$ мікропідприємством, у залежності від доходу застосовується ставка 25\% (якщо оборот менше за 25 тис. євро) або 40\% (якщо оборот перевищує 25 тис. євро). Литва: основна ставка 15\%; для підприємств 3 річним оборотом менше 300 тис. євро та чисельністю працівників менше 10 використовується ставка у 5\%; також за специфічних умов підприємництва існує ставка О\% (вільна економічна зона або великі інвестиційні проєкти з чіткими межами доходу та чисельності працівників).

3) Податок на доходи фізичних осіб. Естонія - 20\% на трудові та інші доходи, у тому числі дивіденди. Латвія використовує прогресивну систему оподаткування фізичних осіб. Якщо дохід менше 20 тис. євро, ставка дорівнює 20\%; якщо дохід особи знаходиться у межах 20 тис. євро та 62,8 тис. євро, застосовується ставка 23\%; Якщо дохід більше за 62,8 тис. євро, ставка дорівнює 31\%. Також існують окремі ставки на здачу житла в оренду (10\%) та доходи від капіталу (20\%). Литва: на трудові доходи менше 81162 євро - 20\%, вище цієї суми - 32\%. Фізичні особи-підприємці мають платити від 5 до 15\% від доходу, також ставкою 15\% оподатковуються дивіденди. Інші доходи також диференційовані: нижче 162324 євро річних - 15\%, вище цієї суми - $20 \%$.

4) Внески соціального страхування. В Естонії основною ставкою є 33\%, також існує страхування від безробіття, підприємство сплачує 0,8\%, працівник сплачує 1,6\%. У Латвії загальна сума дорівнює $34,09 \%$, 3 яких 23,59\% сплачує роботодавець та 10,5\% сплачує працівник. Самозайняті особи сплачують 31,07\% від доходів. Додатково виплачуються суми страхування пенсій у розмірі 5\% та $10 \%$ для самозайнятих осіб. Литва відрізняється від усіх досліджуваних країн тим, що основну суму соціального страхування сплачує не підприємство, а працівник. Сумарна ставка дорівнює 19,5\% (складається 3 12,52\% внесків на соцстрах та 6,98\% на страхування здоров'я). Підприємство сплачує лише 1,79\% від доходу. Самозайняті особи також мають сплачувати 19,5\%, але не від усієї суми доходів, а від 90\% від неї [7].

На рисунку 3 представлений порівняльний аналіз ставок основних податків України, Білорусі та країн Прибалтики.

Як можна побачити 3 даних дослідження, за рідкісним виключенням податкове навантаження у країнах Прибалтики, що входять до складу $€ C$, $€$ дещо більшим за незалежні пострадянські країни. Але незважаючи на більш суттєві податкові виплати, населення Прибалтики є більш щасливим, ніж жителі України та Білорусі. Згідно до щорічного рейтингу країн за рівнем щастя їх населення, на 31 березня 2021 року країни Прибалтики зайняли 38 (Литва), 40 (Естонія) та 51 (Латвія) місця, в той час, як Білорусь посідає 75 позицію, а Україна -110 [8]. 


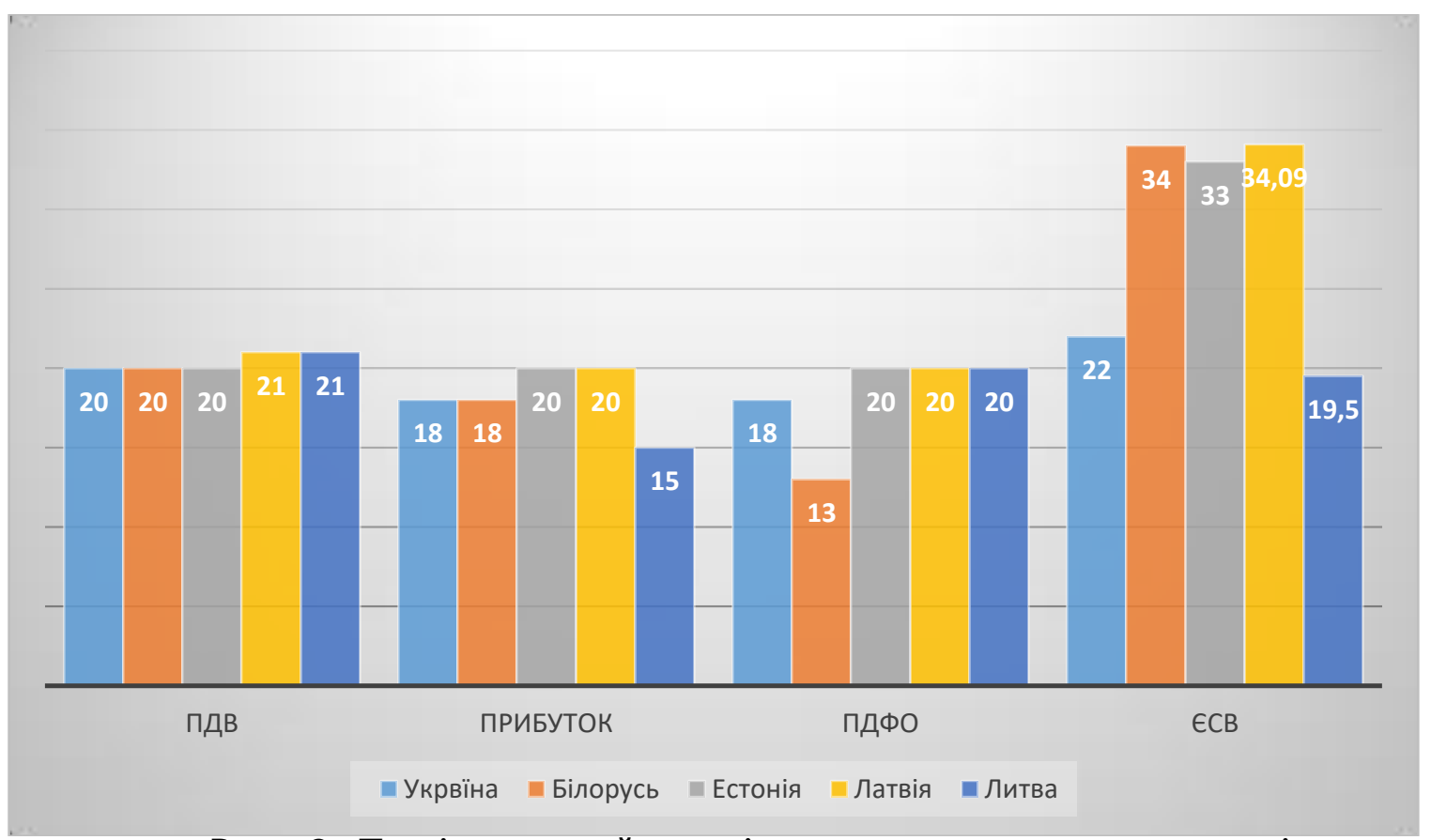

(складено автором)

Податкова система також суттєво впливає на індекс рівня життя країни. На позицію країн у цьому рейтингу мають вплив не тільки ВВП, а й довіра до соціальних та політичних інститутів та соціальних програм, що має прямий зв'язок з оподаткуванням. Отже, завдяки прогресивному оподаткуванню та дещо більшим ставкам у 2021 році країни Прибалтики увійшли у топ-30 країн з найкращим рівнем життя (Естонія на 11 позиції, Литва на 19, Латвія на 30). Україна та Білорусь у цьому рейтингу посідають 59 та 60 місця відповідно [9].

Висновки і перспективи подальших досліджень. Як показав проведений аналіз, прогресивна податкова система $\epsilon$ більш ефективною з точки зору функціонування економіки, підвищення рівня життя населення та його задоволеності проживанням у країні. Незважаючи на більш суттєве податкове навантаження, населення країн Прибалтики є більш задоволеним політичною та соціальною сферами життя та рівнем соціального забезпечення. Прогресивна податкова система та пільги для деяких видів діяльності (IT, інвестиції, розвиток науки) можуть забезпечити Україні суттєвий розвиток економіки, підвищення довіри населення i, як наслідок, зростання рівню життя у країні у цілому.

у подальших дослідженнях автор планує проаналізувати податкові системи більш розвинених країн та можливості переймання їхнього досвіду у оподаткуванні, зокрема у введенні прогресивних податкових ставок та пільг для певних видів підприємницької діяльності.

Література:

1. Офіційний портал Державної фіскальної служби України. URL: http://sfs.gov.ua/korisni-posilannya/slovnik

2. Офіційний вебпортал Парламенту України. URL: https://zakon.rada.gov.ua/laws/main/2755-17\#Text 
3. Сайт бухгалтерського порталу «Дебет-Кредит». URL: https://services.dtkt.ua/catalogues/tax rates

4. Офіційний інтернет-портал Президенту Республіки Білорусь. URL: https://president.gov.by/ru/belarus/economics/nalogi-ibjudzhet/nalogovaja-sistema
5. Сайт
«Экономическая
газета».
URL:

https://neg.by/novosti/otkrytj/stavki-nalogov-v-sravnenii-s-2020-g
$6 . \quad$ Сайт
юридичної
компанії
«равоком».
URL:

https://pravocom.by/statiy/sistemy-nalogooblozheniya-v-rb/

7. Сайт консалтингової компанії «Rödl \& Partner». URL: https://www.roedl.com/en-gb/de/about-

us/locations/latvia/documents/roedl-partner-steuertabelle-est-Iva-Itu2021-ru.pdf
8. Сайт
«Гуманітарний
портал».
URL:

https://gtmarket.ru/ratings/world-happiness-report

9. Сайт світових рейтингів «BaseTop». URL:

https://basetop.ru/rejting-stran-mira-po-urovnyu-zhizni-2021/

References:

1. Oficijnyj portal Derzhavnoji fiskaljnoji sluzhby Ukrajiny. URL: http://sfs.gov.ua/korisni-posilannya/slovnik
2. Oficijnyj
vebportal
Parlamentu
Ukrajiny.
URL:

https://zakon.rada.gov.ua/laws/main/2755-17\#Text

3. Sajt bukhghaltersjkogho portalu "Debet-Kredyt». URL: https://services.dtkt.ua/catalogues/tax rates

4. Oficijnyj internet-portal Prezydentu Respubliky Bilorusj. URL: https://president.gov.by/ru/belarus/economics/nalogi-i-

bjudzhet/nalogovaja-sistema

5. Sayt "Ekonomicheskaya gazeta». URL:

https://neg.by/novosti/otkrytj/stavki-nalogov-v-sravnenii-s-2020-g

6. Sajt jurydychnoji kompaniji "Pravokom». URL: https://pravocom.by/statiy/sistemy-nalogooblozheniya-v-rb/

7. Sajt konsaltynghovoji kompaniji «Rödl \& Partner». URL: https://www.roedl.com/en-gb/de/about-

us/locations/latvia/documents/roedl-partner-steuertabelle-est-lva-ltu2021-ru.pdf

8. Sajt «Ghumanitarnyj portal». URL: https://gtmarket.ru/ratings/world-happiness-report

9. Sajt svitovykh rejtynghiv "BaseTop». URL: https://basetop.ru/rejting-stran-mira-po-urovnyu-zhizni-2021/

The tax system is the basis of the functioning of any state, because the country's budget is formed and filled mainly by taxes and fees. Since 1991, Ukraine's tax system has been in a state of constant reform, moving away from the specifics of Soviet taxation and trying to acquire its own, unique tax policy. In turn, the Republic of Belarus is a less progressive country, whose policy is quite dependent on Russia, and therefore the tax system has long remained almost unchanged and relatively stable. The Baltic countries (Latvia, Lithuania, Estonia) are also post-Soviet, but now they are in a completely different political system, the European Union, so the taxation in these countries is very different 
from other former Soviet republics and is able to adapt to European standards.

It was because of the different political conditions that Ukraine was chosen by the author as a country that severed ties with Russia and other post-Soviet countries and gradually moved towards an alliance with Europe, Belarus, as a country that remains in close contact with Russia, and the Baltic states, which are part of the European Union and have completely different tax systems. The purpose of this article is to analyze the tax systems of Ukraine, Belarus and the Baltic countries, to study their specifics, common and distinctive features.

According to the analysis, a progressive tax system is more efficient in terms of economic functioning, improving living standards and satisfaction with living in the country. Despite the greater tax burden, the population of the Baltic States is more satisfied with the political and social spheres of life and the level of social security. A progressive tax system and benefits for certain activities (IT, investment, science development) can provide Ukraine with significant economic development, increased public confidence and, as a result, an increase in living standards in the country as a whole.

In further research, the author plans to analyze the tax systems of more developed countries and the possibility of adopting their experience in taxation, in particular in the introduction of progressive tax rates and benefits for certain types of business activities.

УДК 331.103

DOI: 10.35340/2308-104X.2021.91-2-15

\section{WELL-BEING-ЯК АДАПТАЦІЙНА ТЕХНОЛОГІЯ УПРАВЛІННЯ ПЕРСОНАЛОМ В ПЕРІОД КРИЗОВИХ ЯВИЩ}

CHOПEHKO Г. В., аспірант, Донецький державний університет управління

\section{WELL-BEING AS AN ADAPTATION TECHNIQUE FOR MANAGING HUMAN RESOURCES IN TIMES OF CRISIS}

\author{
SNOPENKO H. \\ Post-graduate Student, \\ Donetsk State University of \\ Management
}

У статті проаналізовано вплив розвитку технологій на добробут персоналу підприємств і визначено, що розмиті межі між роботою та домашнім офісом збільшують кількість стресу і призводять до вигорання співробітників. Розглянуто сутність "Well-being» технології як одного із методів профілактики синдрому професійного вигорання. Визначено найбільш поширені програми забезпечення добробуту персоналу $і$ запропоновано при формуванні моделі управління персоналом використовувати модель PERLA.

Ключові слова: технології управління персоналом, Well-being, ефективність персоналу, добробут персоналу, вигорання персоналу, залученість персоналу, модель PERLA.

В статье проанализировано влияние развития технологий на благосостояние персонала предприятий и определено, что размытые границы между работой и домашним офисом увеличивают стресс и приводят к выгоранию сотрудников. Рассмотрена сущность «well- 